\title{
AWARENESS OF PATIENTS ON ORAL EXAMINATION AND HYGIENE DURING AND BEFORE PREGNANCY: A SURVEY STUDY
}

\author{
HASTALARIN GEBELİKTE VE ÖNCESİNDE AĞIZ MUAYENESİ VE HİJYENİ \\ KONUSUNDA FARKINDALIĞI: ANKET ÇALIŞMASI
}

Dr. Öğr. Ü. Kübra TÖRENEK AĞIRMAN*

Prof. Dr. Binali ÇAKIR*

Makale Kodu/Article code: 4314

Makale Gönderilme tarihi; 14.02 .2020

Kabul Tarihi: 13.08 .2020

DOI : $10.17567 /$ ataunidfd. 780139

Kübra Törenek Ağırman: ORCID ID: 0000-0001-7200-3436

Binali Çakır: ORCID ID: 0000-0002-8525-1444

\section{ABSTRACT}

Aim: Pregnancy is characterized by complex physiological changes that can adversely affect oral health. Therefore, the utmost attention should be careful about oral hygiene. This study aimed is to investigate the awareness of patients about oral examination and hygiene during and before pregnancy.

Material and Methods: In November and December 2018, the questionnaire we prepared for patients who came to our clinic from 18 years old and above cities and surrounding cities was completed and the results were evaluated statistically.

Results: Of the 380 patients who participated in the study, 251 said that dental examination is necessary before pregnancy. However, $73.5 \%$ ( $\mathrm{n}: 72$ ) of the patients stated that although they went to a gynecologist and obstetrician before pregnancy, $64.3 \%$ (n: 63) did not go to a dentist for a dental examination. Only 34 patients (34.7\%) reported that they applied to a dentist for dental problems during pregnancy. The remaining majority (n: 64; 65.3\%) did not experience any problems with the teeth or go to the dentist, even if they did.

Conclusion: It is very important that patients who apply to various health institutions before pregnancy are informed about the importance of oral examination and directed to the relevant authorities for oral examination. Despite many studies carried out in our country in this regard, it is seen that there is not enough awareness in our region. The multidisciplinary approach of medicine and dentists is of great importance in awareness before and during pregnancy.

Keywords: dentistry; oral health; pregnancy.

Öz

Amaç: Gebelik, ağız sağığını olumsuz yönde etkileyebilecek karmaşık fizyolojik değişiklikler ile karakterizedir. Bu nedenle ağız hijyenine azami özen gösterilmelidir. Bu çalışmanın amacı, hastaların gebelik sürecinde ve öncesinde oral muayene ve hijyen konusundaki farkındalıklarını araştırmaktır.

Gereç ve Yöntemler: 2018 Kasım ve Aralık aylarında, 18 yaş ve üstü şehir ve çevre illerden kliniğimize gelen hastalar için hazırladığımız anket dolduruldu ve sonuçlar istatistiksel olarak değerlendirildi.

Bulgular: Çalışmaya katılan 380 hastadan $251^{\prime} i$ gebelik öncesinde diş muayenesinin gerekli olduğunu söyledi. Bununla birlikte hastaların\% 73,5'i (n: 72) gebeliğinden önce bir jinekolog ve doğum uzmanına gitmesine rağmen,\% 64,3'ü (n: 63) diş muayenesi için bir diş hekimine gitmediğini belirtti. Sadece 34 hasta (\% 34.7), gebelik sürecinde dişlerle ilgili sorunları için bir diş hekimine başvurduğunu bildirdi. Geriye kalan büyük çoğunluğun ise ( $n: 64 ; \%$ 65.3) dişlerde herhangi bir problem yaşamadığı veya yaşamış olsalar bile diş hekimine gitmediği görüldü.

Sonuç: Gebelikten önce çeşitli sağlık kurumlarına başvuran hastaların, oral muayenenin önemi konusunda bilgilendirilmeleri ve oral muayene için ilgili makamlara yönlendirilmeleri büyük önem taşımaktadır. Bu konuda ülkemizde yürütülen pek çok çalışmaya rağmen bölgemizde yeterli farkındalığın oluşmadığı görülmektedir. Tıp ve diş hekimlerinin multidisipliner yaklaşımı gebelik öncesi ve sürecinde farkındalık konusunda büyük önem taşımaktadır.

Anahtar Sözcükler: Ağız sağlığı, Diş hekimliği, Gebelik.

${ }^{*}$ Department of Dentomaxillofacial Radiology, Faculty of Dentistry, Ataturk University, Erzurum, Turkey

Kaynakça Bilgisi: Törenek Ağırman K, Çakır B. Hastaların gebelikte ve öncesinde ağız muayenesi ve hijyeni konusunda farkındalığı: Anket çalışması. Atatürk Üniv Diş Hek Fak Derg 2020; 30: 545-51.

Citation Information: Torenek Agirman K, Cakır B. Awareness of patients on oral examination and hygiene during and before pregnancy: A Survey Study. J Dent Fac Atatürk Uni 2020; 30: 545-51. 


\section{INTRODUCTION}

Pre-pregnancy care is a preventive health service that aims to improve the health of spouses before they have children. The aim is to identify and guide appropriately the medical and social conditions that pose a risk to the mother and the baby before pregnancy. ${ }^{1-5}$

Pregnancy is a very important period in terms of oral health of mothers. Immunological, hormonal and vascular changes during this period accelerate the development of infection in the gums and surrounding tissues. Poor oral hygiene also aggravates this picture.

Because of the limitations in the pregnancy process (x-rays cannot be taken, the time of intervention is limited to the second trimester, etc.) and the patients who do not apply to the dentist except during emergency cases, it is very important to dissolve them before the pregnancy and to inform the patients. Otherwise, irreversible situations and frequent tooth loss may occur after pregnancy.

The aim of this study was to investigate the awareness of patients about oral examination and hygiene during and before pregnancy.

\section{MATERIALS AND METHODS}

\section{Patients}

In 2018 November and December, the questionnaire that we prepared for the patients aged 18 years and over from the city and the surrounding cities to our clinic was completed. The study was carried out with literate female patients over 18 years of age. Illiterate patients, male patients and female patients under 18 years of age were not included in the study. This study was approved by our ethics committee. (Protocol no: 80/ 2018) The study was conducted in accordance with the principles of the Declaration of Helsinki.

Verbal consent and informed written consent were obtained from the women who agreed to participate in the study. The data were collected by face to face interview technique. Each questionnaire took 5 minutes to complete approximately.

In the questionnaire, there are 6 questions about sociodemographic and fertility characteristics of the participants, 12 questions about general oral hygiene and pregnancy process and before and 6 questions about the situations encountered during pregnancy (Figure 1).

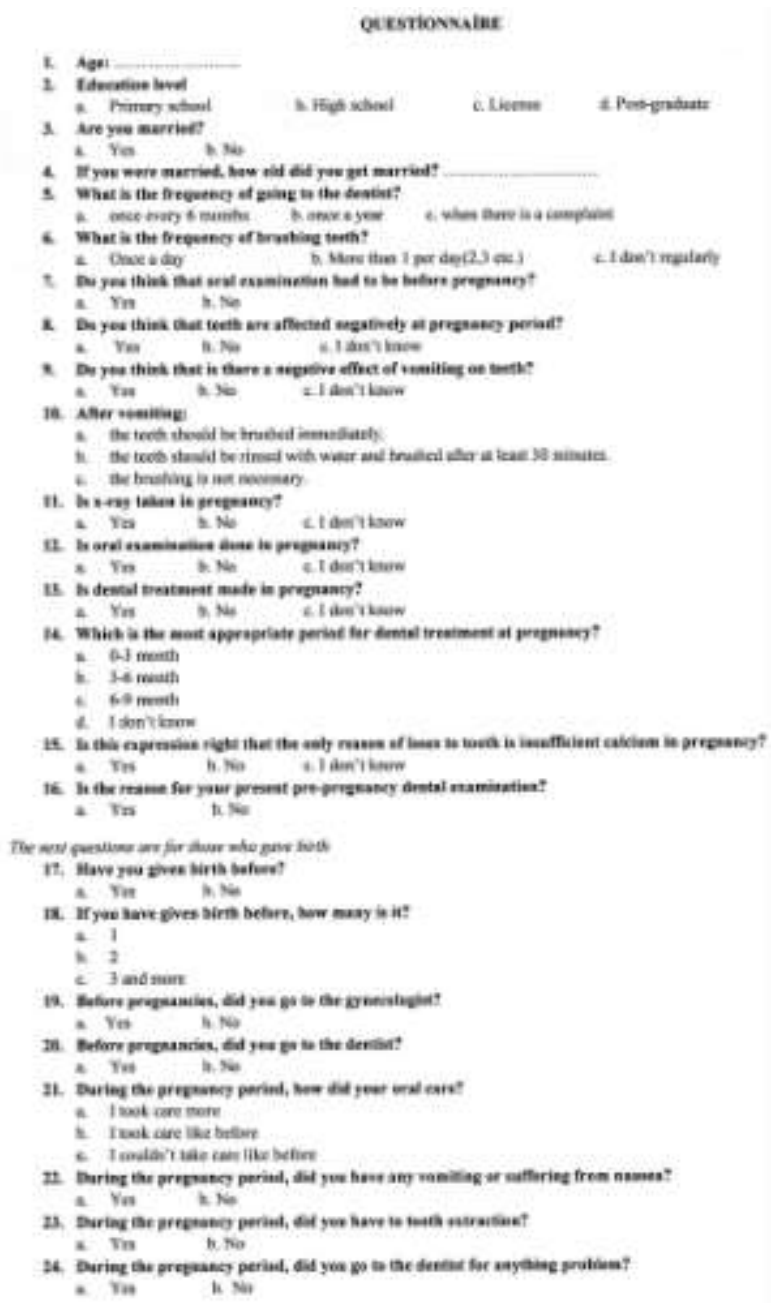

Figure 1. Questionnaire used in the study.

\section{Statistical analysis}

Statistical analysis was performed using SPSS for Microsoft Windows software (version 20.0; SPSS, Chicago, IL, USA). In the evaluation of the data; mean, standard deviation, frequency and percentages were used.

\section{RESULTS}

The descriptive statistics of 380 patients who participated in our study are given in Table 1 . Only 17 of the patients included in the questionnaire were examined for a pre-pregnancy dental examination.

Table 1. Descriptive statistics of patients in the study

\begin{tabular}{|l|c|c|c|c|c|}
\hline & $\mathbf{n}$ & mean & $\begin{array}{c}\text { standard } \\
\text { deviation }\end{array}$ & $\begin{array}{c}\text { minimum. } \\
\text { age }\end{array}$ & $\begin{array}{c}\text { maximum } \\
\text { age }\end{array}$ \\
\hline All patients & 380 & 25,57 & 6,7 & 18 & 50 \\
\hline All married & 131 & 31,25 & 6,8 & 19 & 50 \\
\hline $\begin{array}{l}\text { people who } \\
\text { gave birth }\end{array}$ & 98 & 32,34 & 6,8 & 20 & 50 \\
\hline
\end{tabular}

n: number of patients 


\section{Sociodemographic characteristics of patients}

As seen in Table 2; education level of most of the patients ( $n: 216,56.8 \%$ ) was at the license level and the number of patients at the postgraduate level was the lowest ( $n: 23 ; 6.1 \%$ ). It is observed that the education level of the half of the patients ( $n: 49)$ who gave birth is at the primary school level. 65.5\% ( $n$ : 249 ) of the patients were single; $34.5 \%$ ( $n: 131)$ are married. $79.2 \%$ of the patients ( $n: 301)$ stated that they applied to the dentist only when they complained. $49.5 \%$ of the patients ( $n$ : 188 ) said that they brushed their teeth more than once a day and $15 \%$ ( $n: 57)$ stated that they did not brush their teeth regularly.

Table 2. Sociodemographic characteristics of patients

\begin{tabular}{|c|c|c|c|}
\hline & & $\mathbf{n}$ & $\%$ \\
\hline \multirow{4}{*}{$\begin{array}{c}\text { Education level (all } \\
\text { patient) }\end{array}$} & primary school & 63 & 16,6 \\
\hline & high school & 78 & 20,5 \\
\hline & license & 216 & 56,8 \\
\hline & postgraduate & 23 & 6,1 \\
\hline \multirow{4}{*}{$\begin{array}{c}\text { Education level } \\
\text { (people who gave } \\
\text { birth) }\end{array}$} & primary school & 49 & 50 \\
\hline & high school & 28 & 28,6 \\
\hline & license & 14 & 14,3 \\
\hline & postgraduate & 7 & 7,1 \\
\hline \multirow{2}{*}{ Marital status } & married & 131 & 34,5 \\
\hline & single & 249 & 65,5 \\
\hline \multirow{3}{*}{$\begin{array}{c}\text { The frequency of } \\
\text { going to the } \\
\text { dentist }\end{array}$} & once every 6 months & 33 & 8,7 \\
\hline & once a year & 46 & 12,1 \\
\hline & when there is a complaint & 301 & 79,2 \\
\hline \multirow{3}{*}{$\begin{array}{l}\text { The frequency of } \\
\text { brushing teeth }\end{array}$} & once a day & 135 & 35,5 \\
\hline & more than 1 per day $(2,3$ etc. $)$ & 188 & 49,5 \\
\hline & $\begin{array}{l}\text { people who don't brush them } \\
\text { teeth regularly }\end{array}$ & 57 & 15 \\
\hline
\end{tabular}

\section{Propositions and frequencies about all patients}

251 patients $(66,1 \%)$ who participated in the study said that dental examination is necessary before pregnancy. The number of patients who think that the teeth are adversely affected by the pregnancy process and do not know is almost the same and a high rate was found. $63.3 \%$ of the patients ( $n$ : 229) said that they did not know whether vomiting had a negative effect on the teeth or not. The majority of patients; he stated that $\mathrm{x}$-rays are not be taken during pregnancy (n: 263; 65\%), however, a dental examination can have during pregnancy ( $\mathrm{n}: 203 ; 53.4 \%$ ). However, 205 patients $(53.9 \%)$ stated that they did not know whether they could undergo dental treatment in pregnancy. 'Is the only reason of loses a tooth insufficient calcium in pregnancy?' that was asked. This is a common discourse in society. The number of correct ( $\mathrm{n}: 88 ; 23.2 \%$ ) and wrong answers ( $\mathrm{n}$ : 97; $25.5 \%$ ) was found to be almost closed, and the majority of the patients ( $\mathrm{n}: 195 ; 51.3 \%$ ) did not say to know (Table 3).

Table 3. Propositions and frequencies about all patients

\begin{tabular}{|l|c|c|c|c|}
\hline \multicolumn{2}{|l|}{} & yes & no & $\begin{array}{c}\text { I } \\
\text { don't } \\
\text { know }\end{array}$ \\
\hline $\begin{array}{l}\text { Do you think that oral examination had to be } \\
\text { before pregnancy? }\end{array}$ & $\mathbf{n}$ & 251 & 27 & 102 \\
\cline { 2 - 5 } & $\mathbf{\%}$ & 66,1 & 7,1 & 26,8 \\
\hline $\begin{array}{l}\text { Do you think that teeth are affected } \\
\text { negatively at pregnancy period? }\end{array}$ & $\mathbf{n}$ & 180 & 23 & 177 \\
\hline $\begin{array}{l}\text { Do you think that is there a negative effect of } \\
\text { vomiting on teeth? }\end{array}$ & $\mathbf{\%}$ & 47,4 & 6,1 & 46,6 \\
\hline Is x-ray taken in pregnancy? & $\mathbf{n}$ & 23 & 263 & 94 \\
\cline { 2 - 5 } & $\mathbf{\%}$ & 6,1 & 69,2 & 24,7 \\
\hline Is oral examination done in pregnancy? & $\mathbf{n}$ & 203 & 38 & 139 \\
\cline { 2 - 5 } & $\mathbf{\%}$ & 53,4 & 10,0 & 36,6 \\
\hline Is dental treatment made in pregnancy? & $\mathbf{n}$ & 97 & 78 & 205 \\
\cline { 2 - 5 } & $\mathbf{\%}$ & 25,5 & 20,5 & 53,9 \\
\hline $\begin{array}{l}\text { Is this expression right that the only reason } \\
\text { of loses tooth is insufficient calcium in } \\
\text { pregnancy? }\end{array}$ & $\mathbf{n}$ & 88 & 97 & 195 \\
\cline { 2 - 5 } & $\mathbf{\%}$ & 23,2 & 25,5 & 51,3 \\
\hline
\end{tabular}

n: number of patients; \%: percentiles

Most of the patients ( $n: 230 ; 60.5 \%$ ) know that after vomiting, the teeth should be rinsed with water and brushed after at least 30 minutes. The 98 patients $(25.8 \%)$ said that the teeth should be brushed immediately but 52 patients $(13.7 \%)$ said that brushing is not necessary. The majority of the patients (n: $247 ; 65.1 \%$ ) stated that they did not know which period was most suitable for dental treatment in pregnancy. 67 patients $(17.6 \%)$ said the first trimester, 21 patients (5.5\%) said the third trimester.

\section{Propositions and frequencies just about people who gave birth}

Table 4 presents the statistical data of married and patients who gave birth. The number of births of patients showed almost equal distribution. Although $73.5 \%$ ( $n: 72$ ) of the patients went to a gynecologist and obstetrician before their pregnancy, 64.3\% (n: 63) did not go to a dentist for a dental examination.

Table 4. Propositions and frequencies just about people who gave birth

\begin{tabular}{|c|c|c|c|}
\hline & & 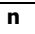 & $\%$ \\
\hline \multirow{3}{*}{$\begin{array}{l}\text { How many times have you given } \\
\text { birth? }\end{array}$} & 1 & 34 & 34,7 \\
\hline & 2 & 34 & 34,7 \\
\hline & 3 and more & 30 & 30,6 \\
\hline \multirow{2}{*}{$\begin{array}{l}\text { Before pregnancies, did you go to } \\
\text { the gynecologist? }\end{array}$} & yes & 72 & 73,5 \\
\hline & no & 26 & 26,5 \\
\hline \multirow{2}{*}{$\begin{array}{l}\text { Before pregnancies, did you go to } \\
\text { the dentist? }\end{array}$} & yes & 35 & 35,7 \\
\hline & no & 63 & 64,3 \\
\hline \multirow{3}{*}{$\begin{array}{l}\text { During the pregnancy period, how } \\
\text { did your oral care? }\end{array}$} & I took care more & 20 & 20,4 \\
\hline & $\begin{array}{l}\text { I took care like } \\
\text { before }\end{array}$ & 46 & 46,9 \\
\hline & $\begin{array}{l}\text { I couldn't take care } \\
\text { like before }\end{array}$ & 32 & 32,7 \\
\hline \multirow{2}{*}{$\begin{array}{l}\text { During the pregnancy period, did } \\
\text { you have any vomiting or suffering } \\
\text { from nausea? }\end{array}$} & yes & 71 & 72,4 \\
\hline & no & 27 & 27,6 \\
\hline \multirow{2}{*}{$\begin{array}{l}\text { During the pregnancy period, did } \\
\text { you have to tooth extraction? }\end{array}$} & yes & 11 & 11,2 \\
\hline & no & 87 & 88,8 \\
\hline \multirow{2}{*}{$\begin{array}{l}\text { During the pregnancy period, did } \\
\text { you go to the dentist for anything } \\
\text { problem? }\end{array}$} & yes & 34 & 34,7 \\
\hline & no & 64 & 65,3 \\
\hline
\end{tabular}


Almost half of the patients ( $n: 46 ; 46.9 \%$ ) stated that they showed the same oral care as before at pregnancy period. $72.4 \%$ ( $n: 71$ ) of the patients had nausea and vomiting during pregnancy. Few patients (n: $11 ; 11.2 \%$ ) had a tooth out during pregnancy and only 34 patients (34.7\%) applied to a dentist for a dental problem during pregnancy. The majority ( $n: 64$; $65.3 \%$ ) did not have any problems with the teeth or did not go to a dentist even though they lived.

\section{DISCUSSION}

Oral changes during pregnancy appear dependent on the hormonal changes within this period. Professional prophylaxis, oral hygiene, and specialist consultancy can reduce the frequency and levels of dental problems. ${ }^{12}$

Research shows that the rate of going to the dentist during pregnancy is not at the desired level. ${ }^{6,7}$ Pregnant women do not go to the dentist because of financial difficulties, lack of dental discomfort, unnecessary vision, lack of importance, the effects of not knowing on pregnancy, attitudes of dentists and obstetricians to access dental services are factors such as. ${ }^{8-13}$

In literature, it is stated that pregnant women are one of the important public health problems that should be emphasized due to insufficient oral hygiene and lowering the quality of life of women. ${ }^{6,14-19}$ The deterioration of oral dental health causes risky situations for both mother and baby. In studies conducted, the risk of preterm delivery, low birth weight and preeclampsia was found to be high in pregnant women with poor oral hygiene. ${ }^{20-25}$ In studies, it is stated that oral and dental health during pregnancy is a topic that is ignored by obstetricians, midwives and nurses including pregnant women and it is stated that pregnant women are not given counseling and education for oral and dental health. $11,13,14,19,26$ According to Köse et al., 22 as in general health services, preventive treatment services should be at the forefront in oral and dental health. This is important in terms of improving the general oraldental health level of society and in early detection of emerging problems and minimizing costs.

Most of the patients participating in our study brushed their teeth more than once a day, but the dentist's complaint is quite going. It was observed that the majority of patients knew that the teeth could be adversely affected by vomiting and pregnancy and what they should do after possible vomiting. Patients generally know that they can have a dental examination during pregnancy but cannot have x-rays, but most patients are unaware that they can undergo dental treatment when needed. If it is necessary to have dental treatment during pregnancy, the most appropriate period is not known by the patients, but it is seen that it is appropriate to have it in the first months of pregnancy.

In the literature, it is stated that the frequency of going to the dentist during pregnancy is between $35 \%$ and $50 \% .^{6,7}$ In this study, it was found that the rate of going to the dentist in her current pregnancy was a little low $(34,7 \%)$ and most of the participants had no habit of going to the dentist regularly. Most of them gone only when they had a problem with the tooth. It is reported that pregnant women went to the dentist only when they had dental problems. 7,18,28,29 In New Zealand, only $32 \%$ of pregnant women, $35 \%$ in the United States, $58.3 \%$ in the United Arab Emirates, $61 \%$ in the UK, $90 \%$ in Denmark and In Kuwait, $50 \%$ stated that they went to the dentist during pregnancy. ${ }^{7,9,11,14,18,30}$ In the studies done, it is reported that the rate of going to the dentist in groups with low socioeconomic status and not going to regular dentists is very low. ${ }^{8-11,31,32}$ In this study, the reason for the low number of dental visits during pregnancy is explained by the fact that the women who were taken to the research sample do not have the habit of going to the regular dentist, the lack of socioeconomic status, and the coming from a rural region consisting of poorer families. In Iran, the reasons for not going to the dentist in pregnancy of pregnant women is stated as the fear of the dentist and the lack of dental problems. ${ }^{28}$ In New Zealand, $37 \%$ of pregnant women stated that they had no information about the need to go to a dentist during pregnancy. ${ }^{7}$ When the studies are examined, it is seen that women do not go to the dentist because they do not have any problems in their pregnancy. ${ }^{11,28}$ As stated at the end of the study by Özcan et al., ${ }^{34}$ it is necessary to raise the awareness of the community about the oral and dental examination at certain intervals and to be warned not to expect pain to go to the dentist.

Most of the patients who gave birth had gone to a gynecologist before pregnancy but did not go to a dentist. Morgan et al in his survey with obstetric and gynecology experts, $38 \%$ of the participants did not recommend dental treatment in pregnancy, $77 \%$ of patients were determined to prohibit patients from 
going to the dentist. ${ }^{35}$ When this is considered, it is important to inform and guide the patients who apply to the gynecologists before and during the pregnancy. Gynecologists have a major role in this.

In a study, it was determined that taking prenatal care was a factor affecting tooth-brushing habits. ${ }^{36}$ In the studies performed, women who did not take prenatal care were found to have low rates of going to the dentist during pregnancy and it was determined that they did not develop correct behaviors towards oral health. ${ }^{6,11}$ In the literature, it is reported that the higher the education level of women, the higher the rate of taking prenatal care and the higher the tendency to health protective behaviors of individuals with high educational status. 36 Therefore, this result is thought to be related to women's educational status. Prenatal care is one of the main preventive health services that provide early diagnosis and treatment of health problems that may occur before or during pregnancy. Problems related to oral dental health are preventable. For this reason, oral and dental examination as a part of routine prenatal care is important to prevent oral health problems in pregnancy. The education level of the majority of the patients in our study was at the undergraduate level and $66.1 \%$ of all patients stated that dental examination is necessary before pregnancy. However, $64.3 \%$ of those who gave birth did not go to the dentist before pregnancy. This may be explained by the fact that half of the patients who have given birth are primary school graduates. In this context, it is possible to say that new generation mothers are more conscious and the current situation is getting better.

There are some limitations to this article. The low number of patients is the limitation of this study and studies with larger populations are needed. Another one was that the patients' income level was not questioned, and those who gave birth and did not give birth were considered as a single population, not as separate study groups.

It is generally known that oral hygiene awareness before and during pregnancy is low in our country. However, actual studies on this subject could not be found in the literature, available studies were generally done by healthcare professionals other than dentists, and our faculty which serves our city and the environment will help us to have an idea about the region as it may be helpful. Some such situations have forced us to do such a study.
As a conclusion; it is of great importance that the patients who apply to various health institutions before pregnancy are referred to the relevant authorities for oral examination and to inform them about its importance.

\section{CONCLUSIONS}

- The multidisciplinary approach of medicine and dentists is of great importance before and during pregnancy.

- Education of oral hygiene at pregnancy should be given especially single patients.

- A dental form should be requested from couples applying for marriage, similar to the medical report requested. Completion of the necessary dental treatments and asking for a medical report on oral hygiene will be helpful in increasing the awareness of patients on this issue.

- Emphasizing the importance of oral hygiene by explaining the changes that may occur in mouth and teeth during pregnancy.

- Preventing complications during pregnancy should be applied to preventive therapies.

- Physicians should evaluate the oral hygiene of pregnant patients and direct patients with poor oral hygiene to the dentist.

- Patients are told that dental treatment is effective and safe during pregnancy and the rates of using health institutions and dentistry should be increased.

- It is recommended to carry out further studies on this subject with more patients throughout the country and take the necessary steps.

\section{Acknowledgements}

The authors declare that there were no other contributors involved in this work.

Conflicts of interest statement

The authors declare no conflict of interest.

\section{REFERENCES}

1. Johnson K, Posner SF, Biermann J, Cordero JF, Atrash HK, Parker CS, et al. Recommendations to improve preconception health and health care United States. A report of the CDC/ATSDR Preconception Care Work Group and the Select Panel on Preconception Care. MMWR 2006; 55: 123. 
2. Kirkham C, Harris S, Grzybowski S. Evidence-based prenatal care: Part I. General prenatal care and counseling issues. Am Fam Physician 2005; 71: 1307-16.

3. Moos MK, Dunlop AL, Jack BW, Nelson L, Coonrod $D V$, Long $R$, et al. Healthier women, healthier reproductive outcomes: recommendations for the routine care of all women of reproductive age. Am J Obstet Gynecol 2008; 199: 280-9.

4. Atrash $\mathrm{H}$, Jack BW, Johnson K, Coonrod DV, Moos $M K$, Stubblefield PG, et al. Where is the "W"oman in MCH? Am J Obstet Gynecol 2008; 199: 259-65.

5. Jack BW, Atrash $\mathrm{H}$, Coonrod DV, Moos MK, O'Donnell J, Johnson K. The clinical content of preconception care: an overview and preparation of this supplement. Am J Obstet Gynecol 2008; 199: 266-79.

6. Habashneh R, Guthmiller JM, Levy S, Johnson GK, Squier C, Dawson DV, et al. Factors related to utilization of dental services during pregnancy. J Clin Periodontol 2005; 32: 815-21.

7. Honkala S, Al-Ansari J. Self-reported oral health, oral hygiene habits, and dental attendance of pregnant women in Kuwait. J Clin Periodontol 2005; 32: 809-14.

8. Rakchanok N, Amporn D, Yoshıda Y, Rashıd HO, Sakamoto J. Dental caries and gingivitis among pregnant and non-pregnant women in chiang mai, thailand. Nagoya J Med Sci 2010; 72: 43-50.

9. Karunachandra NN, Perera IR, Fernando G. Oral health status during pregnancy: rural-urban comparisons of oral disease burden among antenatal women in Sri Lanka. Rural and Remote Health 2012; 12: 1902.

10. Kazemy $H$, Mohseni $H$, Oskouie SF, Haghani $H$. The Association between knowledge, attitude and performance in pregnant women toward dental hygiene during pregnancy. Iran J Nurs 2005; 18: 31-8.

11. Hashim R. Self-reported oral health, oral hygiene habits and dental service utilization among pregnant women in United Arab Emirates. Int J Dent Hyg 2012; 10: 142-6.

12. Kılınç G, Koca $H$. Oral health during pregnancy and the clinic appearance of pregnancy tumor (Case Report). J Dent Fac Ata Uni. 2015; 24: 29-32.

13. George A, Johnson M, Duff M, Ajwani S, Bhole S, Blinkhorn $A$, et al. Midwives and oral health care during pregnancy: perceptions of pregnant women in south-western Sydney, Astralia. J Clin Nurs 2011; 21: 1087-96.

14. Offenbacher S, Katz V, Fertik G, Collins J, Boyd D, Maynor G, et al. Periodontal infection as a possible risk factor for preterm low birth weight. J Periodontol 1996; 67: 1103-13.

15. Xiong $X$, Buekens $P$, Fraser WD, Beck J, Offenbacher S. Periodontal disease and adverse pregnancy outcomes: a systematic review. BJOG 2006; 113: 135-43.

16. Pitiphat W, Joshipura KJ, Gillman MW, Williams PL, Douglass CW, Rich-Edwards JW. Maternal periodontitis and adverse pregnancy outcomes. Community Dent Oral Epidemiol 2008; 36: 3-11.

17. Ruma M, Boggess K, Moss K, Jared H, Murtha A, Beck J, et al. Maternal periodontal disease, systemic inflammation, and risk for preeclampsia. Am J Obstet Gynecol 2008; 198: 389.

18. Vergnes J. Studies suggest an association between maternal periodontal disease and preeclampsia. Evidence Based Dentistry 2008; 9: 46-7.

19. Shetty M, Shetty PK, Ramesh A, Thomas B, Prabhu $S$, Rao A. Periodontal disease in pregnancy is a risk factor for preeclampsia. Acta Obstet Gynecol Scand 2010; 89: 718-21.

20. Christensen LB, Jensen D, Peterson P. Selfreported gingival conditions and self-care in the oral health of Danish women during pregnancy. J Clin Periodontol 2003; 30: 949-53.

21. Saraç A, Kümbüloğlu Ö, Hatipoğlu HA, User A. The relationship between prevalence of periodontal disorder and social status in dental students (Epidemiological study). J Fac Dent Cumhuriyet Uni 2007; 10: 10-5.

22. Köse S, Güven D, Mert E, Eraslan E, Esen S. The effectiveness of oral hygiene training in 12-13 age group children. J Anatolian Nurs and Health Sci 2010; 13: 44-52.

23. Gökalp $S$, Doğan Güçiz $B$, Tekçiçek $M$ Berberoğlu A, Ünlüer Ş. The oral health profile of 5, 12 and 15 year olds, Turkey-2004. J Hacettepe Uni Dent 2007; 31: 3-10.

24. Detman LA, Cottrell BH, Denis-Luque MF. Exploring dental care misconceptions and barriers in pregnancy. Birth 2010; 37: 318-24.

25. Claas BM, Ellison-Loschmann L, Jeffreys M. Selfreported oral health care and access to oral health information among pregnant women in Wellington, New Zealand. J N Z Med Assoc 2011; 124:37-50. 
26. Mangskau KA, Arrindell B. Pregnancy and oral health: utilization of the oral health care system by pregnant women in North Dakota. Northwest Dent $1996 ; 75: 823-8$.

27. Timothé $P$, Eke PI, Presson SM, Malvitz DM. Dental care use among pregnant women in the United States reported in 1999 and 2002. Prev Chronic Dis 2005; 2.

28. Marchi KS, Fisher-Owens SA, Weintraub JA, Yu Z, Braveman PA. Most pregnant women in california do not receive dental care: findings from a population-based study. Public Health Rep 2010;125:831-42.

29. Wilder R, Robinson C, Jared HL, Lieff S, Boggess K. Obstetricians' knowledge and practice behaviors concerning periodontal health and preterm delivery and low birth weight. J Dent Hyg 2007;81:81.

30. Thomas NJ, Middleton PF, Crowther CA. Oral and dental health care practices in pregnant women in Australia: a postnatal survey. BMC Pregnancy and Childbirth 2008; 8:13-9.

31. Hamissi J, BakianianVaziri P, Davalloo A. Evaluating Oral Hygiene Knowledge and Attitude of Pregnant Women. Iranian J Publ Health 2010;39:28-31.

32. Kısa S, Zeyneloğlu S. Inpatient postpartum women's status of oral hygiene habits and visit to the dentist during their most recent pregnancy. TAF Prev Med Bull 2013;12.

33. Cruz G, Roldos I, Puerta D, Salazar C. Community based, culturally appropriate oral health promotion program. N Y State Dent J 2005; 71:34-8.

34. Özcan E, Evcil S, Turgut H, Yıldız M. An evaluatıon between the applicatıon reason-education level and settlement-tooth brushıng habit in the patients applıed to faculty clınıcs. J Dent Fac Ata Uni 2005; 15: 15-9.

35. Morgan MA, Crall J, Goldenberg RL, Schulkin J. Oral health during pregnancy. J Mat Fet Neonatal Med 2009; 1:1-7.

36. Turan T, Ceylan SS, Teyikçi S. Influencing factors and situation of the mothers to take regular prenatal care. FIrat Uni J Health Sci 2008; 3: 15771.

\section{Sorumlu Yazarın Yazışma Adresi}

Dr. Öğr. Üyesi Kübra TÖRENEK AĞIRMAN

Department of Dentomaxillofacial Radiology, Faculty of Dentistry, Ataturk University, 25240, Erzurum, TURKEY

Business telephone number: 904422311794

Fax number: +90 4422360945

E-mail address: ktorenek@gmail.com 